\title{
社会構造の変化と今後の薬剤師のあるべき姿
}

\author{
狭間研至
}

\section{The Novel Image of Pharmacist of a Super-aged Society in Japan}

\author{
Kenji Hazama \\ Pharmedico, Co., Ltd.; 1-9-5 Tenjinbashi, Kita-ku, Osaka 530-0041, Japan.
}

(Received July 31, 2012)

\begin{abstract}
The percentage of the population over age 65 in Japan was greater than $23 \%$ in 2010 . Therefore, Japan is the world's first "super-aged society", and our country needs a new regional health care system. Our medical systems face many challenges, such as this increase in elderly population with chronic diseases, maintenance of universal health insurance and free access to hospitals, and expensive health care costs. It is not easy to change the current health care system without a sufficient number of doctors. On the other hand, Japan's curriculum in pharmaceutical education has been expanded to six years to establish a new profession of pharmacist. Rapid progress in the market of pharmacies in accepting prescriptions since 1974 has caused pharmacists to primarily act as "technicians". But this is not the best way to solve the serious problems of Japanese medical systems. I want to present the image of a next-generation pharmacist (Pharmacist 3.0), to be involved in the idea of collaborative drug therapy management (CDTM) in this article. The total optimization of our medical supply system with all medical and pharmaceutical specialists is necessary in Japan.
\end{abstract}

Key words_— Pharmacist 3.0; collaborative drug therapy management (CDTM); vital sign; physical assessment

\section{はじめに}

わが国の高齢化率は $23 \%$ を超え，世界初の「超 高齢社会」へと突入しているが, 今後, 団塊の世代 が後期高齢者になる 2025 年に向けてわが国は新し い地域医療システムを構築していく必要に迫られて いる. 一方，高齢者人口・慢性疾患の増加，国民皆 保険制度とフリーアクセスの堅持，かつ医療費適正 化という互いに相反する事柄のバランスをとるため には，現在の医療制度についての型通りの改革では 容易ではない. とくに地域医療現場での医師不足と いう問題については，医師の偏在だけでなく絶対的 な不足もあるとされるが，その解決策の 1 つとして 多職種協働によるチーム医療の推進が挙げられてい る.

その一方で, 薬剤師の教育課程が 6 年制に移行 し, 新たな薬剤師職能の確立が求められている. 1974 年以後の医薬分業の急速な進展のなかで,「応

The author declares no conflict of interest.

ファルメディコ株式会社（†530-0041 大阪市北区天神

橋 1-9-5-3F)

e-mail: mdhazama@gmail.com

本総説は, 日本薬学会第 132 年会シンポジウム S30 で

発表したものを中心に記述したものである.
需した処方箋（処方オーダー）を的確に鑑査し，迅 速・正確に調剂したのち，患者にわかり易い服薬指 導とともにお薬をお渡しして，一連の行動と思考の 内容を薬歴に記載する」（Fig. 1）という業務の質 的向上に力が注がれてきた。しかし，少子超高齢社 会の地域医療システムの中で薬局が医療提供施設と して機能するためにはこのパラダイムからの脱却が 必要である。

本稿では, 医師及び薬局経営者, そして薬学教 育・生涯教育に係わる立場から，21 世紀にふさわ

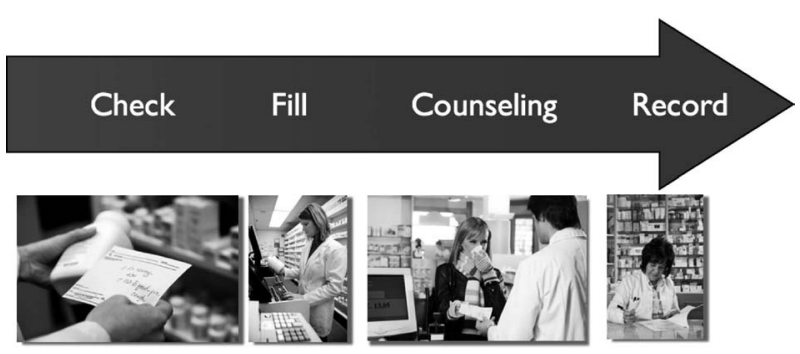

Fig. 1. The Complete Task of Pharmacists

Many pharmacists think their tasks begin with checking a prescription and end with recording the facts of dispensing it. This is not natural for other medical professionals, because they have responsibility after prescribing a treatment for patients. Pharmacists, too, should maintain their interest in their patients after giving medicine, both at pharmacies and in hospitals. 
しい次世代型薬剤師（=薬剤師 3.0）のあるべき姿 について，共同薬物治療管理（collaborative drug therapy management; CDTM) ${ }^{1)}$ の概念も踏まえて考 察してみたい.

\section{「薬」の業界に漂う閉塞感}

現在，「薬」にまつわる業界では様々な閉塞感が 存在する.

薬学部では 6 年制が開始されたことによる，医学 部や看護学部など医療系の他学部との兼ね合いや, 新設薬学部の増加も相まっての定員確保の困難さ と, 他の学部も共通の問題を抱えるにせよ, 学生の 基礎的学力の低下を危惧する声もしばしば耳にする.

また, 薬局では分業率の到達点が視野に入り始 め, 成長率は頭打ちとなり，「医療機関の近隣に出 店し，多数の処方箋を応需する」ことを目的とした ビジネスは成熟期に入っている。薬剤師不足も相ま って, 今後, トップシェアが $15-20 \%$, 売上高 1 兆 円に達する企業が醸成されていくのではないかとい う予想もある中で，中小の薬局チェーン，個人経営 の薬局がどのような方向性を持つべきか，不透明だ と感じる方も多い.

病院では，分業率の上昇に伴い，外来患者の調剤 業務は軽減傾向にあるものの院内・外来の化学療法 への主体的な参画，治験業務やジェネリック医薬品 への対応など院内の様々な業務に加え，いよいよ本 格化した薬剤師の病棟常駐に向けた取り組みを迫ら れる中，方向性が不明瞭に感じられている方もいる ようである。

また，医療費適正化のかけ声の下，薬価は下がり 続けており，医薬品卸という立ち位置も変貌が迫ら れる中，経営統合が急速に進み，価格や物流での差 異を出すことは難しくなっている。

さらには，製薬会社にとっても，薬価引き下げだ けでなく, 先発メーカーにとってはジェネリック推 進の政策が，ジェネリックメーカーにとつては，先 発メーカーのエスタブリッシュ薬としての参入が, そして，日本の製薬メーカー全体にとっては，グ ローバル化の波が，それぞれ大きな影響を及ぼして いる.

まさに，薬を学ぶ，創る，売る，流通させる，使 うという分野において，残念ながら，今後の明るい 展望が開けているとは言い難い.

\section{あえて語りたい「べき論」}

こういう，いわば混迷の時代には，あえて「べき 論」を語っていくのがよいのではないだろうか．す なわち，今，日本の薬剤師は，「薬」業界は，そし て日本の医療や日本という国，さらに世界はどうあ るべきかということを，医療という現場にどっぷり と身をおくからこそ見えてくる視点から語るべきで はないかというのが私の考えである.

この「べき論」は，医療に限らず様々な業界で語 られることが多いが，その際には現在，過去，未来 を俯瞰していくことが重要である，過去の位置づけ は，ある程度論理的に可能であるが，これからのあ るべき像の基本となる未来予測は，意外に難しい． 例えば，21 世紀にはヒト型ロボットが町を闊歩 し，都市にはチューブ状のルートが張り巡らされそ の中を無数の浮遊型の乗り物が行き来するといつた サイエンスフィクションの予測は，フィクションで ありそれでよいと言えばよいが，なかなか容易では ないことを，私たちは実感している.

しかし，医療における基本的な未来予測は大きく 様相が異なる．医療技術の進歩や，社会保険制度の 変革など，多くの外部要因に影響を受ける部分は別 として，人口構造という何よりも堅いデータが，今 後の数十年のあり方の基本として，ほぼ来るべき未 来として提示されている.

あわせて, 昨今の病理・病態学の進歩によって, がんを含めた多くの生活習慣病の発病メカニズムが 明らかにされ，それらの危険因子や抑制因子の解明 もすすんでいる.

また，医療という分野で考えれば，医療系国家資 格者の養成は, 文部科学省や厚生労働省で綿密に計 画されており，医学部や薬学部の数，定員に加え て，過去数十年のデータがある国家試験の合格率， その後の就労率などから, 今後の需給予測について もある程度信頼性のある統計が発表されている.

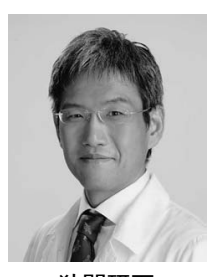

狭間研至
医師・医学博士。ファルメディコ株式 会社代表取締役社長。日本在宅薬学会 理事長. 1995 年大阪大学医学部卒業 後, 同附属病院研修医（第一外科）. 1996 年大阪府立病院消化器一般外科. 1998 年宝塚市立病院呼吸器外科. 2000 年大阪大学大学院医学系研究科㵴器制 御外科. 2004 年同修了後, 現職。現在 に至る. 
さらには，社会保障サービスとしての医療を考え たときに，それらの維持・向上に伴う費用について も，国家予算及び，その中から医療費に割り当て可 能な比率など, 比較的堅い数字があり, 現状はそれ らのトレンドをフォローするような形で並んでいる.

このように考えると，民゙のような方を対象に，民゙ のようなメンバー構成で, どの程度の費用をかけて 行うかという予測がある程度可能な業界が，医療業 界ではないだろうか.

\section{要介護高齢者の在宅での薬物治療}

私は，わが国の文化や消費を形作ってきた団塊の 世代が後期高齢者にシフトする 2025 年に向けての 医療業界のトレンドは，このような社会的な背景を もとに読み解くことが可能ではないかと考えている.

2025 年には年間 160 万人が亡くなる「多死時代」 が到来するが, その頃の療養型病床, 介護老人保健 施設, 介護老人福祉施設の定員数を考えれば，多く は在宅か，近年急速に制度の整備がすすんでいる サービス付き高齢者住宅など在宅に準ずる施設な ぞ，患者・利用者の状況に応じた医療・介護サービ スが外付けされた生活の場で亡くなる時代にシフト していく.

また, 疾病構造についても, メタボリックシンド ロームの広がりや依然として高めで推移している喫 煙率を考えると, 今後 15 年は動脈硬化によって引 き起こされる心疾患, 脳血管疾患, 腎疾患などが増 加するとともに，喫煙が大きな危険因子となるがん や chronic obstructive pulmonary disease (COPD; 慢性閉塞性肺疾患）も増えていくことが予想され る. その一方では, 救急や急性期医療は, 医療機器 や医療技術，治療学の進歩に支えられた治療成績は 向上していくが, このことは, 心疾患や脳血管疾患 で致命的な状況に陥つた場合も，幸いにして一命を 取り留めることができるということになる。これ は，もちろんすばらしいことだが，見方を変える と, 重篤な合併症・後遺症を有しながら長期にわた る医療・介護のサポートが必要な状態になる患者が 増加していくということにもなる.

このように考えると, 今後 15 年の間に, わが国 での医療の現場は「要介護高齢者の在宅での薬物治 療」が多く求められていくと考えられ，実際に，現 在その端緒は開かれつつある.

\section{医師の処方のゆらぎ}

要介護高齢者が独居で過ごさざるを得ない状況で は，服薬コンプライアンスは当然のことながら低下 する. その結果, 大量の残薬が発見されたり, 誤つ た用法・用量で医薬品が使用されたりといつたケー スが発生している．薬剤師の主体的・積極的な在宅 医療への介入によって, 残薬が減少する場合の経済 的インパクトは決して小さくないが，私は，本質は もう少し別のところにあると考えている.

すなわち，服薬コンプライアンスが低下している ということは, 医師が意図した薬物治療がきちんと 行われていないということである。しかも，急性疾 患ではなく慢性疾患の慢性期にある方がほとんどの 要介護高齢者の薬物治療において，医師は定期的 に，場合によっては，計画的訪問診療の契約を結ん で患者の診察を行う。その際には，前回処方した医 薬品が，完璧とは言わずともおおむね処方箋に記載 した通りに使用されたものとして診察するが, 服薬 コンプライアンスの低下は医師にとっては診察する 際の前提条件が崩れていることになる.

例えば，降圧剤や血糖降下薬がきちんと服用され ないことを知らずに，医師が患者を診察すれば，血 圧や血糖のコントロールが不十分と判断し，新たな 投薬を行う可能性が高い. もちろん，このような現 象は, 一般の外来診療においても従来から存在した はずだが, 要介護高齢者の在宅での薬物治療におい ては，これらの問題点は極めて大きくなる.

さらに, 従来の青年期・壮年期の患者と異なり, 既往歴や併用薬, 肝腎機能のばらつきや燕下機能の 低下など, 患者の状態が大きく異なるため, 添付文 書通りの用法・用量では薬物が至適血中濃度に留ま らない可能性が大きくなる.

すなわち，医師が処方内容を決断する前提条件が ゆらぎ，さらに，その用法・用量の妥当性がゆらい でいるケースが, 今現在でも少なからず存在し，そ れが, 今後 15 年にわたつて, 増加しつづけるので はないかと考えている.

\section{薬剤師のある「べき」姿}

さて, このような医療における問題点と今後の予 測が明らかになってくると, 薬剤師のあるべき姿が 浮き彫りになってくる.

わが国の医療の現場の多くで直面する,「要介護 高齢者の在宅での薬物治療」という問題について, 


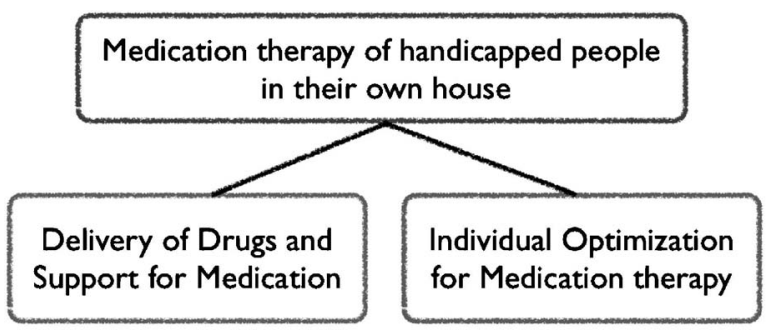

Fig. 2. Medical Topics of Concern in Japan's Super-aged Society

Major medical topics of concern in Japan, which has transitioned into a super-aged society, include not only the delivery of drugs and support for patients taking drugs accurately, but also the optimization of medication for individuals.

薬剤師はなにをするべきか。当然，従来の流れで調 剤したお薬を適切に配薬し，効果的な服薬支援を行 うことが必要になる。しかし，これを薬剤師業務の メインと考えると行き詰まる。薬剤師はそのことを 俯瞰，指示しながら，自らは，患者毎の個別化のた めにその専門性を発揮し，医薬品の適正使用，医療 安全の確保に全力を注ぐべきである（Fig. 2).

このことは，薬剤師法第一条に示された「国民の 健康な生活を確保する」という目的, 医療法に示さ れた「医療従事者」としての薬剤師の姿とも合致す る.

そして，このような変化を生み出すためには，薬 剤師の仕事を今一度，とらえ直す必要があるだろう。

すなわち，医師からの処方箋や処方オーダーを応 需した後，適切な処方箋鑑査を行い，迅速・正確に 調剂した後，的確な服薬指導とともに患者に薬剤を 渡し，それら一連の事実を薬剤師によるアセスメン トとともに薬歴に記載するという，これを打破する ヒントは, 当該患者に対する薬凨師の業務を, 薬歴 管理で終わらせないというところにあるのではない かと私は考えている.

例えば，私も医師としてカルテを記載するが，そ こに書くのは，患者の状態や自分が行った診察や処 置の内容だけではない。それはむしろ事実としての メモ程度であり，重要なのは，今後どのようなこと が予想されそれに対して，どのような治療計画を持 つて臨むのかという未来への予測である.

診察時には, 前回のカルテの内容をチェックし, 自らがたてた今後の予測と, 今現在の患者の状態, 治療行為の成果が合致しているかどうかをチェック するし，チーム医療を進めていく中では，これらの
情報を，自分以外の医師や他の医療従事者と共有で きるようにしておくことは，医療の質的向上に極め て重要な役割を持つはずである.

つまり，チーム医療の一員としての薬剤師も，前 回自分が予測した未来が本当に到達しているかどう かをチェックするために，薬学的専門性を存分に発 揮して患者の状態をアセスメントするべきであり, 医師と同じように薬歴という医療記録を記載した後 も，患者とともに併走し，業務がスパイラルで回っ ていくような立ち位置へとシフトすべきだと私は考 えている. そして，このことは奇しくも，平成 23 年秋発行の調剂指針（第十三改訂）の冒頭に示され た「調剤の概念」において「薬物療法を患者に対し て個別最適化を行い実施すること」「薬剂を交付し た後も，その後の経過の観察や結果の確認を行い, 薬物療法の評価と問題点を把握し，医師や患者にそ の内容を伝達する」と明記されたイメージにほかな らない，すなわち，調剤とは，まさに，時代は，薬 剂師がそうある「べき」と方向性を示しているので はないだろうか.

\section{手段としてのバイタルサイン}

この数年, 私も取り組んできた薬剤師にとっての バイタルサイン, フィジカルアセスメント2)は，こ のような薬剂師の「べき論」の文脈で考えると，単 なる手段でしかないということに気がつくし，さら には，あるべき薬剤師像を具現化・実践するには, 不可欠のツールであることも腑に落ちて頂けるので はないだろうか.

ボディタッチや血圧測定などの法的意義について は，もはやその是非を語るフェーズは過ぎている が，地域医療や薬剤師職能における意義について は，まだまだ理解が進んでいない。むしろ，知れば 知るほど，薬剤師にとつては不要ではないかという 疑念が高まるだけという傾向すらあるし，その論理 的背景も理解できる.

しかし，それは，薬剤師としてのある「べき」姿 を薬剤師のみの文脈で考えているからではないかと 感じられる．前述してきたこれからの地域医療のあ り方，今後のわが国の社会保障のあり方まで広げて 考えてみるとバイタルサインの手技や知識は，あく までも薬剤師が患者の状態をアセスメントするため の手段である，それが有効に活用できれば，医療薬 学・医薬品情報学の知識を合わせて患者の状態を評 
価できる（=フィジカルアセスメント）。さらに, フィジカルアセスメントができれば，薬剤師として 医薬品の適正使用, 医療安全の確保の観点から, 薬 剤師がチーム医療の plan-do-check-act cycle (PDCA) サイクルに入っていくことができるが，それは，結 果的に共同薬物治療管理（CDTM）と呼ばれるも のになるだろう。

昨今のこれらのテーマに関する混乱は，医療全体 から俯瞰した薬剂師の「べき論」が語られることな く，これらの手技や行為や概念そのものが目的化し ていることにあるのではないかと感じている.

バイタルサインもフィジカルアセスメントも, 共 同薬物治療管理も，この国で薬剤師が果たすべき役 割を考えていったときに，必要となるツールであり 手段であり，すべての目的は「国民の健康な生活を 確保する」という医師法, 薬剤師法第一条に共通す るものに収斂するはずである.

おわりに

薬剤師が持ってきた従来の仕事の概念では，今後 勃興するわが国の地域医療ニーズに応えることがで きないし，その結果が，今の「薬」業界が感じる様 々な閉塞感ではないかと考えている.

私自身は，「薬」業界のパラダイムシフトが，近 い将来起こると考え，その一端を担うことができれ
ばと思い活動を進めてきたが，それは，決して「薬」 業界の閉塞感の打破や，薬剂師の社会的地位や認知 度の向上を目的としていたわけではない，結果的に そうなればいいと感じるし，そうなるだろうが，根 底にあるのは，本稿で述べてきたようなわが国の医 療に横たわる大きな問題を何とかしたいという思い である。

これから 15 年，わが国の医療は大変な状況に直 面する確率は極めて高い。そのときに，薬剤師の働 き方が大きく変わり，中でも医師との関係が「医師 が処方し，薬剤師が調剤する」というものを越えて 「共同薬物治療管理」ともいうべき新しい連携を組 むことができれば，日本の医療はもっとすばらしい ものとなるだろうし，そのことへの確信は，この数 年の薬剤師との協働の中で医師として固まってきた.

このような薬剤師のあり方の変化は，薬学部の教 育のあり方を変え，薬局のビジネスモデルを第 3 世 代の薬局 $(=\text { 薬局 3.0 })^{3)}$ へと変え, 病院の収益構造 を変え，ひいては，医薬品の開発・販売・流通のモ デルを変え，冒頭に述べたような「薬」業界の持つ 閉塞感の払拭へとつながっていくのではないかと感 じている.

さらに，もう少し話を広げれば，世界で最初に超 高齢社会というカテゴリーに突入し，世界最高長寿

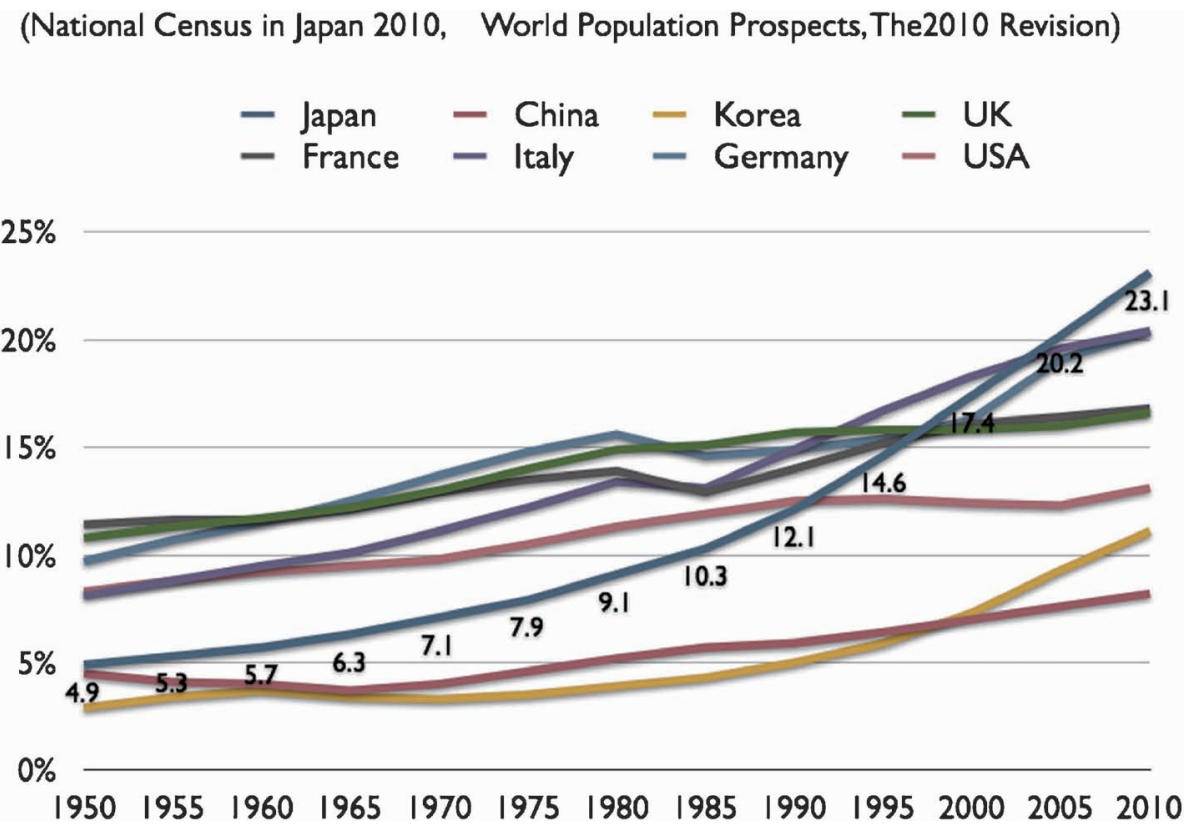

Fig. 3. Trends in the Population Rate of the Elderly

Japan is the first country to enter into a super-aged society in the world. In the next two or three decades, China, Korea, and many of the European countries will confront the same problem Japan is facing now. 
を，対 GDP 比では OECD 平均以下の医療費を投 入するだけで達成しているわが国の「多職種連携・ 情報共有型」の地域医療モデルは, 今後, 高齢化率 の上昇が本格化する諸外国にとっては，高い国際競 争力を持つものとなるはずである (Fig. 3).すな わち，日本にとってこれから取り組もうとしている 新しい地域医療モデルの構築は，立国のための重要 かつ有効な方策であるだけでなく，広く世界に貢献 していくためにも大きな意義を持つ.

このような高い視点から，わが国の医療の現状や 課題を俯瞰したときに，今後の地域医療の進むべき 方向は明確に見えるはずであるが，その原動力の一
つが「薬学教育 6 年制」への移行に伴う薬剤師のあ り方の大きな変化であるということを強調し，本稿 を終えたい.

\section{REFERENCES}

1) Hazama K., Yakugaku Zasshi, 132, 17-20 (2012).

2) Hazama K., Iyaku no Mon, 48, 198-201 (2008).

3) Hazama K., "Pharmacy 3.0," YAKUJI NIPPO LIMITED, Tokyo, 2008, pp. 132-142. 